\title{
Corrigendum: Bifactor analysis and construct validity of the Five Facet Mindfulness Questionnaire (FFMQ) in non-clinical Spanish samples
}

\begin{abstract}
Jaume Aguado ${ }^{1}$, Juan V. Luciano ${ }^{1,2 *}$, Ausias Cebolla ${ }^{3,4}$, Antoni Serrano-Blanco 1,2, Joaquim Soler ${ }^{5,6}$ and Javier García-Campayo ${ }^{2,7}$

${ }^{1}$ Teaching, Research \& Innovation Unit, Parc Sanitari Sant Joan de Déu, Sant Boi de Llobregat, Spain, ${ }^{2}$ Primary Care Prevention and Health Promotion Network (redIAPP), Madrid, Spain, ${ }^{3}$ Department of Basic and Clinical Psychology and Psychobiology, Universitat Jaume I de Castelló, Castellón de la Plana, Spain, ${ }^{4}$ Fisiopatología de la Obesidad y la Nutrición (CIBERobn), Madrid, Spain, ${ }^{5}$ Department of Psychiatry, Hospital de la Santa Creu i Sant Pau, Barcelona, Spain, ${ }^{6}$ Centre for Biomedical Research in Mental Health (CIBERSAM), Madrid, Spain, ${ }^{7}$ Department of Psychiatry, Aragon Institute of Health Sciences, Miguel Servet Hospital, Zaragoza, Spain
\end{abstract}

Keywords: Five Facet Mindfulness Questionnaire, bifactor model, structural equation modeling, anxiety, depression

\section{OPEN ACCESS}

Edited and reviewed by: Holmes Finch,

Ball State University, USA

*Correspondence: Juan V. Luciano

jvluciano@pssjd.org

Specialty section: This article was submitted to Quantitative Psychology and Measurement, a section of the journal Frontiers in Psychology

Received: 25 April 2016 Accepted: 27 April 2016 Published: 09 May 2016

Citation:

Aguado J, Luciano JV, Cebolla A,

Serrano-Blanco A, Soler J and

García-Campayo J (2016) Corrigendum: Bifactor analysis and construct validity of the Five Facet Mindfulness Questionnaire (FFMQ) in non-clinical Spanish samples.

Front. Psychol. 7:706.

doi: 10.3389/fpsyg.2016.00706

\section{A Corrigendum on}

Bifactor analysis and construct validity of the Five Facet Mindfulness Questionnaire (FFMQ) in non-clinical Spanish samples

by Aguado, J., Luciano, J. V., Cebolla, A., Serrano-Blanco, A., Soler, J., and García-Campayo, J. (2015). Front Psychol. 6:404. doi: 10.3389/fpsyg.2015.00404

Reason for Corrigendum:

In the original article, we have neglected to thank our sponsor Instituto de Salud Carlos III (ISCIII)-Network for Prevention and Health Promotion in Primary Care (redIAPP, RD12/0005/0006 \& RD12/0005/0008), co-financed with European Union ERDF funds. The authors apologize for this oversight. This error does not change the scientific conclusions of the article in any way.

\section{AUTHOR CONTRIBUTIONS}

All authors listed, have made substantial, direct and intellectual contribution to the work, and approved it for publication.

Conflict of Interest Statement: The authors declare that the research was conducted in the absence of any commercial or financial relationships that could be construed as a potential conflict of interest.

Copyright (c) 2016 Aguado, Luciano, Cebolla, Serrano-Blanco, Soler and García-Campayo. This is an open-access article distributed under the terms of the Creative Commons Attribution License (CC BY). The use, distribution or reproduction in other forums is permitted, provided the original author(s) or licensor are credited and that the original publication in this journal is cited, in accordance with accepted academic practice. No use, distribution or reproduction is permitted which does not comply with these terms. 